\title{
EDITORIAL
}

DOI: $10.11606 /$ issn. $1982-677$ X.rum.2020.177125

\section{0 anos da televisão no Brasil e a expansão da cultura audiovisual}

RuMoRes, revista científica dedicada aos estudos de comunicação, linguagem e mídias, em sua $28^{a}$ edição, destaca e reconhece o valoroso histórico da produção audiovisual nacional considerando especialmente o marco dos 70 anos da entrada da televisão no país - contando a partir do dia 18 de setembro de 1950, em que se realizou a primeira transmissão de televisão aberta e observando as possibilidades inovadoras contemporâneas na produção televisiva, na popularidade dos sistemas de streaming e nas transformações do modelo seriado. No dossiê Ficções televisivas: deslocamentos e rupturas, organizado pela editora convidada Amanda Souza de Miranda, pós-doutoranda na ECA/USP, e por Rosana de Lima Soares, revisamos fronteiras genéricas da produção televisiva, entre suas narrativas ficcionais, desde séries e produtos especiais até telenovelas ou seriados, tanto em termos de seus repertórios como também de seu acervo de imagens.

Esse debate ganha maior relevância em tempos de isolamento social devido à crise sanitária causada pela Covid19, em que a vivência dessas produções puderam ser os olhos de muitos para as ruas, quando não podíamos estar nelas, cortando distâncias espaciais, além de terem estabelecido outras dinâmicas de experimentação com as telas plurais em que estamos inseridos, vendo e sendo vistos. Radicaliza-se, assim, tanto nossa relação com o audiovisual como com os efeitos de suas narrativas, com destaque para o que elas evocam no entretenimento, no debate sobre representatividade e nos modos de se olhar a sociedade.

Além dos dez artigos trazidos no Dossiê, nessa edição Marcio Serelle, em "Narrativa sobre um poder afável: trabalho e racionalidade neoliberal em Estou me guardando para quando o carnaval chegar" nos conduz a Toritama (PE), por meio do documentário de Marcelo Gomes, para discutir sobre mídia, estética e 
discursos sobre o trabalho visibilizando sua precarização e tentando redimensionar seu valor na vida humana. Essa viagem pelo espaço, quando chega aos ambientes digitais, tem um desejo de alcançar territórios globais. Pensando as narrativas de ficção nacionais no ambiente de streaming, Carlos Pereira Gonçalves, em "Fluxos, mediações e narrativas: o processo de comunicação dos gêneros audiovisuais de ficção em webséries brasileiras da Netflix", observa os processos de distribuição dessas produções, entre possibilidades e restrições, e discute os limites de sua classificação genérica.

O ambiente digital se caracteriza também pela interação com os públicos que se manifestam com sua variedade cultural e territorial. Apontamos para um ambiente de ódio, violência e controle de dados aproveitando-se da mesma abertura e possibilidade de assumir o ambiente das novas mídias como espaço de produção relevante, como nos indica Júlia Cavalcanti Versiani dos Anjos em "A violência da vigilância: discursos sobre tecnologia na série You", debatendo temas como interações digitais, vigilância e privacidade. Discutindo os limites do uso tecnológico e das plataformas de streaming, chegamos à lógica das redes sociais, como vemos com Paula Coruja em "Público: a audiência performática em caixas de comentários no YouTube", que busca apontar quem é esse público e categorizar sua performance como comentadores, além de recuperar seus grandes temas. Uma resenha completa o corpo da edição: "O diálogo social solidário na ressignificação das periferias", de Julio Cesar Gonçalves, sobre o livro de Mara Rovida, oferecendo um recorte geográfico e territorializado para as práticas comunicacionais e retomando a noção de a interatividade como diálogo social solidário.

Na mesma linha desse diálogo coletivo, reforçamos nosso empenho em manter este lugar de divulgação científica, mesmo em tempos de grandes desafios, que é RuMoRes - as edições deste ano tiveram o apoio do Programa de PósGraduação em Meios e Processos Audiovisuais (PPGMPA-ECA-USP) e, como em outros anos, da Tikinet Edição, responsável pela produção editorial da revista. A eles agradecemos especialmente nesse ano em que contamos, ainda, com o 
empenho de uma comunidade formada ao longo de uma trajetória de mais de dez anos, sustentada pelo grupo de pesquisa MidiAto (ECA/USP) e que, em breve, se expandirá para uma colaboração em rede, a Rede de Pesquisa em Cultura Midiática - Metacrítica.

Sem a presença constante e segura de tantos apoiadores, interlocutores e colaboradores não teríamos atravessado esses anos e, certamente, ao lado deles, seguiremos para os próximos. Sem o apoio assíduo e generoso de nossos leitores, esse esforço não faria sentido. Que em 2021 possamos prosseguir por outros trajetos e consolidar a importância, cada vez mais crescente, de afirmar o espaço da ciência, da cultura, da educação e da universidade como fundamentais para a produção, divulgação e atualização da pesquisa acadêmica divulgada em inúmeros periódicos. A todas e todos os nossos agradecimentos e votos de um novo ano com muita saúde!

MidiAto - Grupo de Estudos de Linguagem: Práticas Midiáticas dezembro de 2020 